\title{
Çekim Merkezi Olarak Kentlerin Pazarlamasında İmajın Oluşumu ve Sadakate Etkisi (The Formation of Image and Its Effect on Loyalty in Marketing Cities)
}

\author{
Ayşe Nevin SERT iD a Yusuf DÜNDAR \\ a Selçuk Üniversitesi, Beyşehir Ali Akkanat Turizm Fakültesi, Konya, Türkiye. nevinsert@selcuk.edu.tr \\ a Hacı Bayram Veli Üniversitesi, Lisansüstü Eğitim Enstitüsü, Ankara Türkiye. ysfdundar42@gmail.com
}

\begin{tabular}{|c|c|}
\hline MAKALE BİLGİSİ & ÖZET \\
\hline $\begin{array}{l}\text { Anahtar Kelimeler: } \\
\text { Bilişsel imaj } \\
\text { Duyuşsal imaj } \\
\text { Genel imaj }\end{array}$ & $\begin{array}{l}\text { Amaç - Turistlerin karar verme sürecinde ve destinasyon seçim davranışında önemli bir faktör } \\
\text { olması nedeniyle destinasyon imajının doğru bir şekilde değerlendirilmesi, etkili bir pazarlama } \\
\text { ve konumlandırma stratejisinin tasarlanmasında önemlidir. Bu çalışmada destinasyon imajı } \\
\text { bilişsel, duyuşsal ve genel imaj olarak bütünsel bir yaklaşımla ele alınmış olup destinasyon } \\
\text { imajının destinasyon sadakatine etkisi incelenmiştir. }\end{array}$ \\
\hline $\begin{array}{l}\text { Destinasyon imaj1 } \\
\text { Destinasyon sadakati }\end{array}$ & $\begin{array}{l}\text { Yöntem - Araştırma inanç ve kültür turizminin merkezi Konya kentinde yerli turistler üzerinde } \\
\text { yapılmıştır. Bu çalışmada veri toplama aracı olarak anket kullanılmıştır. Çalışmada bilişsel imaj, } \\
\text { duyuşsal imaj, genel imaj ve destinasyon sadakati arasındaki ilişkiye yönelik önerilen } \\
\text { hipotezlerin test edilmesinde SPSS programının yardımıyla regresyon analizi kullanılmıştır. }\end{array}$ \\
\hline $\begin{array}{l}\text { Gönderme Tarihi } 15 \text { Aralık } 2018 \\
\text { Revizyon Tarihi } 10 \text { Mart } 2019\end{array}$ & $\begin{array}{l}\text { Bulgular - Çalışma sonucunda destinasyon imajının destinasyon sadakatini etkilediği, } \\
\text { destinasyon imajı oluşumunda bilişsel imajın duyuşsal imaja oranla genel imajı kısmen daha } \\
\text { fazla etkilediği ortaya çıkmıştır. }\end{array}$ \\
\hline $\begin{array}{l}\text { Makale Kategorisi: } \\
\text { Araştırma Makalesi }\end{array}$ & $\begin{array}{l}\text { Tartışma - Destinasyon imajının değerlendirilmesi ve analizi, turist davranışının daha iyi } \\
\text { anlaşılmasına önemli bir katkıda bulunmaktadır. Olumlu destinasyon imajını oluşturmaya veya } \\
\text { geliştirmeye yönelik çabalar, sadık ziyaretçilerin tekrar ziyaret veya tavsiye etme davranışlarını } \\
\text { kolaylaştırır ki söz konusu durum destinasyonun turizm gelişimi konusundaki başarısı için } \\
\text { kritik öneme sahiptir. Zengin doğal, tarihi ve kültürel kaynakları olan destinasyonların olumlu } \\
\text { bir imaj yaratmada fiziksel özelliklerini geliştirmeye daha çok önem vermeleri gerekmektedir. }\end{array}$ \\
\hline ARTICLE INFO & ACT \\
\hline $\begin{array}{l}\text { Keywords: } \\
\text { Cognitive image } \\
\text { Affective image } \\
\text { Overall image }\end{array}$ & $\begin{array}{l}\text { Purpose - Due to the fact that tourists are an important factor in decision making process and } \\
\text { destination selection behaviour, accurate assessment of destination image is important in } \\
\text { designing effective marketing and positioning strategy. In this study, destination image has } \\
\text { been evaluated with a holistic approach as cognitive, affective and overall image. Also the effect } \\
\text { of destination image on destination loyalty has been examined }\end{array}$ \\
\hline $\begin{array}{l}\text { Destination image } \\
\text { Destination loyalty }\end{array}$ & $\begin{array}{l}\text { Design/methodology/approach - The study was conducted on the domestic tourists in Konya } \\
\text { where is the centre of faith and cultural tourism. A questionnaire was used as data collection } \\
\text { tool. In the study, in order to test proposed hypotheses for the relationship between cognitive } \\
\text { image, affective image, general image and loyalty of destination, regression analysis was used } \\
\text { with the help of SPSS program. }\end{array}$ \\
\hline $\begin{array}{l}\text { Received } 15 \text { December } 20 \\
\text { Revised } 10 \text { March } 2019 \\
\text { Accepted } 22 \text { March } 2019\end{array}$ & $\begin{array}{l}\text { Results - A major finding of the study was that destination image is formed by affected, } \\
\text { cognitive and the overall image. Also destination image affected the destination loyalty, and } \\
\text { that in the formation of destination image the cognitive image partially affected the overall } \\
\text { image compared to the affective image. }\end{array}$ \\
\hline $\begin{array}{l}\text { Article Classification: } \\
\text { Research Article }\end{array}$ & $\begin{array}{l}\text { Discussion - The evaluation and analysis of the destination image makes a significant } \\
\text { contribution to a better understanding of tourist behaviour. Efforts to create or develop a } \\
\text { positive destination image encourage the re-visiting or recommendation behaviour of loyal } \\
\text { visitors, which is a key factor for the success of the destination in regard to tourism. } \\
\text { Destinations with rich natural, historical and cultural resources need to pay more attention to } \\
\text { improving their physical characteristics in creating a positive image. }\end{array}$ \\
\hline
\end{tabular}




\section{Giriş}

Destinasyon imajıyla ilgili çalışmalar, 1970'lerin başlarında Hunt'ın (1975) imajın turizm gelişimindeki rolünü incelemesiyle ve imaj ile destinasyon rekabeti arasındaki ilişkiyi belirlemesiyle başlamıştır denilebilir. 1990'lı yıllarda hız kazanan çalışmalar ile destinasyon imajı günümüzde turizm araştırmalarının ilgi gören alanlarından biri haline gelmiştir (Beerli ve Martin, 2004; Pike, 2016). Günümüzde, destinasyon imajının karar verme ve seçme sürecinde oynadığı rolün önemi konusunda genel bir fikir birliğine varılmıştır denilebilir (Baloğlu ve Mangaloglu, 2001; Beerli ve Martin, 2004; Pike, 2016).

Turizm ürünü soyut ve birbirinin benzeri olduğu için destinasyonlar arası rekabet imajlar aracilığı ile gerçekleşmektedir (Baloğlu ve Mangaloğlu, 2001; San Martin ve del Bosgue, 2008). Dolayısıla destinasyonların olumlu ve akılda kalıcı bir imaj geliştirerek kendilerini rakiplerinden ayırt etmeleri, potansiyel ziyaretçilerin zihninde olumlu bir izlenim oluşturmaları son derece önemlidir (Baloğlu, Henthorne ve Sahin, 2014). Böyle bir imaj, kişilerin gelecekte o destinasyonda yine iyi bir deneyim yaşayacaklarına dair inançlarını artıracağından destinasyonun tekrar tercih edilme olasılığı artacak ve kişilerin destinasyona olan bağlllıklarını pekiştirecektir (del Bosque ve San Martin, 2008).

Taşcı, Gartner ve Çavuşgil (2007) destinasyon imajının turizm destinasyonlarının nasıl görüldüğü ve hissedildiği ile ilgili olduğunu belirtmiştir. Kişilerin psikolojik, sosyal özellikleri (cinsiyet, yaş, eğitim, medeni durumu vb.), bilgi kaynaklarının çeşitliliği ve türü ile önceki deneyimlerin turist destinasyonunun algılanan imajı üzerinde etkiye sahip olduğu çeşitli çalışmalarda ortaya konulmuştur (Baloğlu ve McCleary, 1999b; Beerli ve Martin, 2004; San Martin ve del Bosque, 2008). Yapılan çalışmalarda (Baloğlu ve Mccleary, 1999a, 1999b; Baloğlu ve Mangaloğlu, 2001; Beerli ve Martin, 2004; Hosany, Ekinci, ve Uysal, 2007; Taşc1 vd., 2007; Stylidis, Shani ve Belhassen, 2017) destinasyon imajının birbiriyle yakından ilişkili üç bileşenin etkileşimi sonucu oluştuğu görülmektedir: (1) bilişsel imaj (2) duyuşsal imaj (3) genel imaj. Turizm ürün ve hizmetlerinin çok boyutlu (Tascı vd., 2007) ve soyut (Fakeye ve Crompton, 1991) olmasının getirdiği karmaşık yapı nedeniyle destinasyon imajı ölçümünde bu üç bileşenin incelenmesi gerektiği öne sürülmektedir (Stylidis vd., 2017).

Chen ve Tsai, (2007), destinasyon imajının davranışsal niyetler (tekrar ziyaret etme ve istekli olma isteği) üzerinde de önemli etkiye sahip olduğunu ileri sürmüştür. Özellikle destinasyon sadakati üzerine yapılan çalışmalar (Chen ve Tsai, 2007; del Bosque ve San Martín, 2008; Prayag ve Ryan, 2012; Chen ve Phou, 2013; $\mathrm{Wu}, 2016)$ destinasyon imajının turist sadakati üzerinde doğrudan, dolaylı ya da hem doğrudan hem de dolaylı etkisi olduğunu ortaya koymuştur. Tekrar eden satın almalar ve tavsiye etme (Yoon ve Uysal, 2005) olarak tanımlanan destinasyon sadakati, davranışsal, tutumsal ve bileşik sadakat olmak üzere ele alınıp ölçülmektedir. Davranışsal sadakat, tekrar satın alma sıklığına; tutumsal sadakat, bir kişinin bir destinasyon hakkındaki olumlu hislerini; bileşik sadakat ise her ikisinin karışımı olarak tanımlanır.

Destinasyon imajıyla ilgili çeşitli çalışmalar yapılmıştır ancak, destinasyon imajını bilişsel ve duyuşsal faktörlerle birlikte bütünsel bir yaklaşımla ele alıp (Pike, 2002) destinasyon sadakati ile olan ilişkisini yerli turistler bağlamında inceleyen çalışma sayısının az olduğu (Sun, Chi ve Xu, 2013; Tan ve Wu, 2016; Stylidis vd., 2017; $\mathrm{Xu}$ ve Ye, 2018) görülmüştür. Bununla birlikte yapılan çalışmalar genellikle popüler uluslararası destinasyonlarda yabancı turistlerle gerçekleştirilmiştir. Bu çalışmada ise çalışma alanı olarak Konya şehri seçilmiştir. İnanç ve kültür turizm merkezi olan Konya iç turizme yönelik Türkiye'nin en popüler turistik destinasyonlarından birisi olarak kabul edilmektedir. Uzun yıllar (1097-1307 tarihleri arasında) Anadolu Selçuklu Devleti'nin başkentliğini yapmış olması ve Mevlana Celaddin-i Rumi'nin türbesinin bulunması Konya'nın önemini artıran önemli unsurlar olarak öne çıkmaktadır. İçinde Hz. Mevlana'nın türbesi de bulunan Mevlana Müzesi 2017 yılında 2480433 ziyaretçi sayısıyla Türkiye'de en çok ziyaret edilen müze olmuştur (Kültür ve Turizm Bakanlığı, 2018).

Çalı̧̧manın amacı bilişsel ve duyuşsal ve genel imajı bütünsel yaklaşımla ele almak ve destinasyon imajının destinasyon sadakati ile olan ilişkisini ortaya koymaktır. Çalışmadan elde edilen ampirik bulguların, destinasyon yöneticilerine, yerel yönetime ve plan ve politika yapıcılarına, iç turizm objesi olan sadık yerel ziyaretçiler kazanmaları açısından hedefledikleri pazarlar için stratejiler geliştirme konusunda ve turist davranışlarını açıklama konusunda yol gösterici olacağı düşünülmektedir. 


\section{Literatür Taraması}

\subsection{Destinasyon Imajı}

Destinasyon imajı, destinasyonların turistler tarafından nasıl algılandığını anlamak ve olumlu davranışsal niyetleri harekete geçirmek isteyen turizm yöneticilerine önemli bazı bilgiler sunmaktadır. Destinasyon imajının yardımıyla, yöneticiler destinasyonun güçlü ve zayıf yönlerini belirleyebilir ve buna göre pazarlama stratejilerini planlayabilirler. Örneğin, yöneticiler, turistlerin destinasyonla güçlü bir şekilde ilişkilendirdikleri olumsuz bir özelliği tespit ederse, ya bu özellik ile destinasyon arasındaki bağlantıyı (ilişkilendirme gücü) zayıflatmaya ya da olumluluğunu (ilişki değerini) artırmaya çalışabilirler (Kock, Josiassen ve Assaf, 2016). Turistlerin bir destinasyonu nasıl algıladıklarını, zihinlerindeki görüntülerin neler olduğunu anlamak, aynı zamanda turizm talebini tahmin etmede kullanılabildiğinden ve etkin stratejik destinasyon planlamasının temelini oluşturduğundan destinasyon imajıyla ilgili çalışmalar başarılı destinasyon pazarlama stratejilerinin öncülü olarak kabul edilmektedir (Souiden, Ladhari, ve Chiadmi, 2017).

Rekabet açısından bir destinasyonun sahip olduğu asıl özellikleri ve kaynakları kadar önemli olan imaj (Pike, 2016) en kısa şekilde bir yerle ilgili potansiyel ziyaretçilerin sahip olduğu algı (Hunt, 1975) olarak tanımlanmıştır. Echtner ve Ritchie (1991), destinasyon imajını, destinasyonun oluşturduğu bütünsel bir algı olarak tanımlayarak kavramı genişletmişlerdir. En çok referans verilen tanıma göre ise bu algı, bir yerle ilgili inanç, fikir ve izlenimlerin toplamından oluşur (Crompton, 1979). Turizm bağlamında destinasyon imajının kavramsallaştırılmasında ya da ölçülmesinde sistematik bir yapıya ulaşılmamış olduğunu belirten Tascı vd., (2007) ise destinasyon imajının, bir destinasyona yönelik düşüncelerin, fikirlerin, duyguların, görselleştirmelerin ve niyetlerin etkileşiminden oluştuğunu belirtmişlerdir. Literatürde genellikle destinasyon imajı, bir birey veya grubun belirli bir yerle ilgili sahip olacağı tüm nesnel bilgi, izlenim, önyarg1, hayal ve duygusal düşüncelerin ifadesi olarak tanımlanmıştır (Baloğlu ve McCleary, 1999a; Beerli ve Martín, 2004; Baloğlu, Henthorne ve Sahin, 2014; Stylidis vd., 2017).

Tanımlar, kavramın karmaşıklığını ve bir destinasyon imajının oluşumunda yer alan bilişsel ve duyuşsal bileşenlerin dikkate alınması gerektiğini işaret etmektedir (Echtner ve Ritchie, 1991; Chew ve Jahari, 2014; Stylidis vd., 2017). Daha önceki çalışmalarda, sadece destinasyon imajının bilişsel bileşenlerinin dikkate alınmış olduğunu (Echtner ve Ritchie, 1993; Tascı vd., 2007), duyuşsal imajın ise hesaba katılmadığı görülmüştür (Hunt,1975; Fakeye ve Crompton, 1991; Gartner ve Shen, 1992; Ross, 1993; Milman ve Pizam, 1995). Pike (2002) bu konuya işaret ederek 1973 ile 2000 yılları arasında yayınlanmış 142 destinasyon imaj çalışmasından sadece 6 tanesinin duyuşsal imajı değerlendirmeye aldığını belirtmiştir. Ancak son yıllarda giderek artan sayıda araştırmacı, destinasyon imajının, bilişsel ve duyuşsal olmak üzere çok boyutlu bir yapı olduğunu (Hosany, Ekinci ve Uysal, 2007), dolayısıyla hem bilişsel hem de duyuşsal yönleri birleştirilerek çalışılması gerektiğini öne sürmektedir (Baloğlu ve McCleary, 1999a; Baloğlu ve Mangaloglu, 2001; Beerli ve Martin, 2004; Chew ve Jahari, 2014). Baloğlu ve Mangaloğlu (2001), bir destinasyonun sadece fiziksel özelliklerden oluşmadığı bu nedenle bilişsel bileşene odaklanmanın, destinasyon imajını incelemede yeterli olamayacağını ve ölçümle ilgili sorunlara yol açabileceğini öne sürmektedirler. Dolayısıyla bilişsel ve duyuşsal imajın birlikte ele alınmasının destinasyon imajının karmaşık yapısını anlamada gerekli olan derinliği sağladığı söylenebilir (Smith, Li, Pan, Witte ve Doherty, 2015).

Destinasyon imajının hem bilişsel hem de duyuşsal yönleri farklı rollere sahiptir ve etkileri belirli koşullara göre değişmektedir (Souiden vd., 2017). Bilişsel değerlendirme, bir nesneye ilişkin inanç ve bilgi anlamına gelirken (nesnenin niteliklerinin değerlendirilmesi), duyuşsal değerlendirme ise nesne hakkındaki duyguları ifade eder (Baloğlu ve McCleary, 1999a). Bilişsel imaj, kişinin bir yerle ilgili sahip olduğu inanç ve bilgi ile birlikte, o yerle ilgili zihninde bir tablo oluşturmasına yardımcı olan nitelikler olup (Baloğlu ve McCleary, 1999b; Beerli ve Martin, 2004; Stylidis vd., 2017) manzara, iklim, konaklama tesisleri, restoranlar, tarihi ve kültürel cazibeler, yerel halkın tutumu vb. gibi bir destinasyonun sahip olduğu kaynakları da içerir. Ayrıca, destinasyonun, turistlerin rahatını ve güvenliğini sağlamak için gerekli olan yeterli kaynağa sahip olup olmadığına dair algılarıyla (Beerli ve Martín, 2004), hava durumuyla, turistlerin harcadıkları paranın karşılığını alıp almadıklarıyla da (Smith vd.,2015) ilgilidir.

Destinasyon imajını sadece bilişsel olarak ölçmek turistlerin destinasyonla ilgili fikirlerini tam olarak yansıtmayacaktır. Turistlerin destinasyon algılarını daha geniş bir perspektiften ele almak için duygusal bileşenlerden oluşan duyuşsal imaja da yer verilmesi daha doğru bir yaklaşım olacaktır (Tascı ve Gartner, 
2007; Lin, Morais, Kerstetter, ve Hou, 2007; Chew ve Jahari, 2014; Stylidis vd., 2017). Duyuşsal imaj, kişinin bir destinasyona yönelik duygularını ve duygusal tepkilerini ifade eden, soyut özelliklerden oluşmaktadır. Diğer bir deyişle duyuşsal imajın, bir yeri sevip sevmemeye, hoşlanıp hoşlanmamaya, o yerle ilgili inançlara, düşüncelere bağlı olduğu görüşü ağırlık kazanmaktadır. Kısacası duyuşsal imaj bir destinasyonla ilgili bilişsel bilgiye verilen sübjektif ve duygusal tepkilerin toplamıdır (Smith vd., 2015) denilebilir. Baloğlu ve McCleary (1999a), dört semantik diferansiyel skalanın (heyecanlı-sıkıcı, hiç güzel değil-çok güzel, bunaltıc1/yorucu-rahatlatıc1/dinlendirici, sakin/hareketsiz-canlı/hareketli) destinasyon imajının duyuşsal bileşenini belirlemek için kullanılabileceğini belirtmişlerdir. Souiden vd., (2017), turistlerin duyuşsal imaj algılarının, bir tur güzergahındaki duygusal koşullara veya durumlara bağlı olduğundan daha kolay değiştiğini, bilişsel imajın ise bir turizm destinasyonu hakkında önceden edinilmiş bilgi temelinde şekillendiğinden dolayı daha zor değiştiğini ileri sürmüşlerdir. Lin vd. (2007) yaptıkları çalışmada bilişsel ve duyuşsal imaj bileşenlerinin rolünün farklı özellikteki destinasyonlara göre değiştiğini, özellikle, doğal güzelliklere sahip destinasyonların tercih edilmelerinde daha çok destinasyonların bilişsel imajının etkili olduğunu ancak, gelişmiş destinasyonların tercih edilmesinde, hem bilişsel hem de duyuşsal imaj bileşenlerinin etili olduğunu tespit etmişlerdir.

Bilişsel ve duyuşsal imajlar etkileşim içindedirler (Smith vd., 2015). Bilişsel imajın duyuşsal imaj üzerinde önemli bir etkisi vardır. Bireyler önce destinasyon hakkında topladıkları bilgilere dayanarak bilişsel imajı, daha sonra ise duyuşsal imajı oluşturur (Beerli ve Martin, 2004; Chen ve Phou, 2013; Souiden vd., 2017). Teorik olarak, bilişsel imaj, duyuşsal bileşenin öncülü olduğu kabul edilmektedir (Beerli ve Martin, 2004). Buradan yola çıkarak aşağıdaki hipotez önerilmektedir:

H1: Bilişsel imaj duyuşsal imajı pozitif yönde ve anlamlı bir şekilde etkiler.

Destinasyon imajının temel bileşenleri bilişsel, duyuşsal ve genel olmak üzere üç başlık altında tanımlanmıştır (Baloğlu ve McCleary, 1999a). İmajın bilişsel ve duyuşsal boyutları bireyin bir yer hakkında negatif veya pozitif değerlendirmesini özetleyen genel imajı oluşturmaktadır. Bir destinasyonu bilişsel ve duyuşsal olarak değerlendirme sonucunda o destinasyonun genel imajı oluşmaktadır. Diğer bir deyişle destinasyondaki farklı niteliklerin ve özelliklerin etkileşimi sonucunda genel imaj oluşur (Baloğlu ve Mangaloglu, 2001; Tascı ve Gartner, 2007; Chew ve Jahari, 2014; Stylidis vd., 2017). Bu nedenle aşağıdaki hipotezler formüle edilmiştir:

$\mathrm{H}_{2}$ : Bilişsel imaj genel imajı pozitif yönde ve anlamlı bir şekilde etkiler.

H3: Duyuşsal imaj genel imajı pozitif yönde ve anlamlı bir şekilde etkiler.

\subsection{Destinasyon Sadakati}

Seyahat ve turizm alanında önemli bir olgu olarak turist sadakati 1990'lı yıllardan bu yana incelenmektedir (Zhang, Fu, Cai ve Lu, 2014). Oliver (1999) sadakati “kişilerin tercih etmiş oldukları ürün veya hizmetleri, içinde bulundukları koşullara ve karşı pazarlama çabalarına rağmen ileride de devamlılık arz edecek şekilde yeniden satın almaya, müşterisi olmaya yönelik derin bir bağlllık olarak" tanımlar. Yoon ve Uysal'a (2005) göre tüketici sadakati tekrar satın alma ya da tavsiye etmek olup destinasyonlar da bir ürün olarak düşünülebilir ve turistler tekrar ziyaret edebilir, arkadaş veya akraba gibi diğer potansiyel turistlere önerebilir. Destinasyon pazarlamacıları potansiyel turistleri destinasyona çekmeye, gelen turistlerin ise tekrar gelmelerini sağlamaya çalışmaktadırlar (Tan ve $\mathrm{Wu}, 2016$ ). Turistlerin tekrar ziyaret etmelerini veya başkalarına tavsiye etmelerini sağlamak destinasyonda turizm gelişiminin başarısı açısından önemlidir (Oppermann, 2000; Chen ve Tsai, 2007; Yoon ve Uysal, 2005; Zhang vd., 2014).

Turist sadakati, (1) davranışsal sadakat, (2) tutumsal sadakat ve (3) bileşik sadakat olmak üzere üç yaklaşımdan biri kullanılarak kavramsallaştırılıp ölçülmektedir (Jacoby ve Chestnut, 1978). Davranışsal sadakat, marka satın alma sıklığını, oranını veya satın alma olasılığını ölçmeye dayanır. Aslında tekrar ziyaretler gibi davranışsal sonuçlarla ilgilidir (Zhang vd., 2014; Zhang, Wu ve Buhalis, 2018). Kavramsal bir bakış açısı ortaya koyamadığı ve müşteri sadakatini etkileyen faktörleri açıklayamadığı öne sürülerek eleştirilmiştir (Yoon ve Uysal 2005; Zhang vd., 2014). Tutumsal yaklaşım müşterilerin bilinçli sadakati ile sahte/yapay sadakati arasındaki farklılığa dayanmaktadır. Bilinçli müşterilerin aksine sahte/yapay müşterilerin markaya bağlılıkları yoktur, ancak zamanın uygun olması, parasal ödüller, ikame eksikliği, ihtiyacını giderememenin psikolojik baskısı gibi nedenlerle satın alırlar (Oppermann, 2000). Dolayısıyla, bir 
A. N. Sert - Y. Dündar 11/1 (2019) 529-544

markaya karşı olumlu tutum sergilemek, sadakat için yeterli bir gösterge değildir (Yoon ve Uysal 2005; Prayag ve Ryan, 2012). Bileşik sadakat, davranışsal ve tutumsal sadakatin bütünleşmiş halidir (Yoon ve Uysal 2005). Hem markayı satın alan hem de sadakati olan müşterilerin muhtemelen olumlu bir tutuma sahip olduğu varsayılmıştır (Oppermann, 2000). Bununla birlikte, Zhang vd., (2014), operasyonel düzeyde, tekrar ziyaret niyetinin ve diğerlerine tavsiyenin, turist sadakati için en çok kullanılan ölçüm olduğunu iddia etmektedir. Destinasyon imajı, sadakati oluşturmak için güçlü bir araç olarak görülebilir (Zhang vd., 2014). Bir destinasyonu olumlu olarak algılayan turistlerin yeniden ziyaret etme veya başkalarına tavsiye etme olasılıkları daha yüksek olup destinasyon sadakatinin iki ana göstergesi olduğu söylenebilir (Hosany ve Prayag, 2013; Sun vd., 2013). Buradan yola çıkarak aşağıdaki hipotez önerilebilir:

H: Genel imaj destinasyon sadakatini pozitif yönde ve anlamı bir şekilde etkiler.

\section{Yöntem}

\subsection{Araştırma Modeli}

Araştırma modeli Şekil 1'de görüldüğü üzere bilişsel imaj, duyuşsal imaj, genel imaj ve destinasyon sadakati arasındaki ilişkinin analiz edilmesini tanımlamaktadır. Model üzerinde görülen araştırma hipotezlerinin test edilmesinde SPSS programının yardımıyla regresyon analizi kullanılmıştır. Önerilen hipotezlere göre bilişsel imajın duyuşsal imajı ve genel imajı, duyuşsal imajın ise genel imajı, genel imajın da destinasyon sadakatini etkileyeceği beklenmektedir.

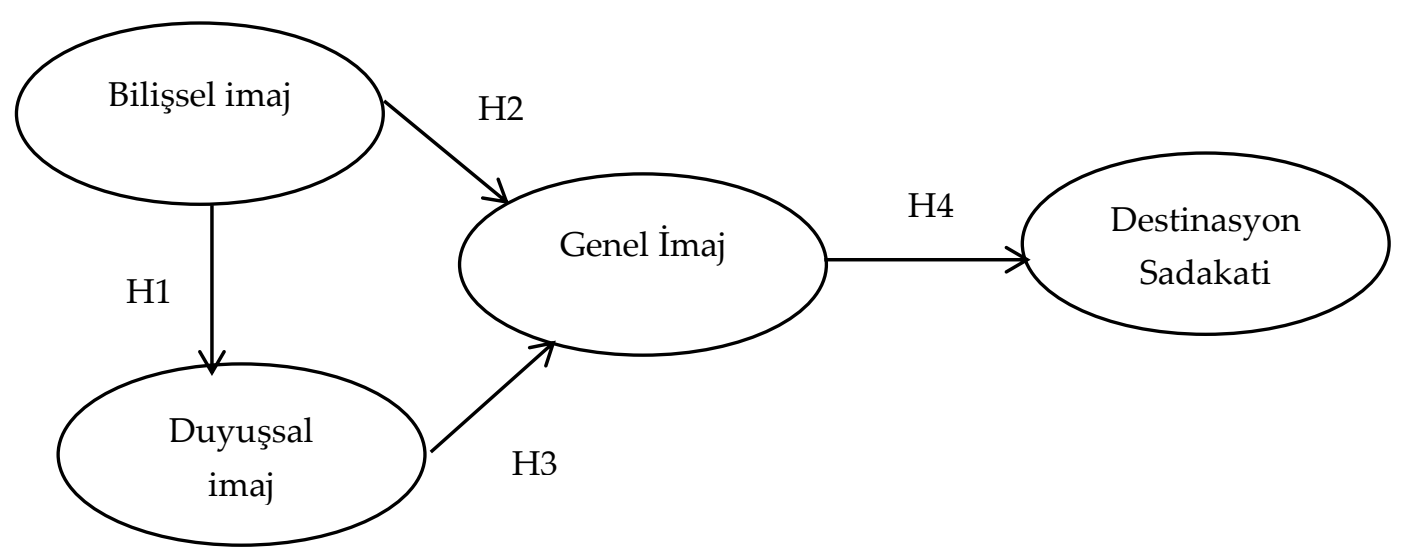

Şekil 1. Araştırma modeli ve hipotezler.

\section{2. Ölçme Aracı}

$\mathrm{Bu}$ çalışmada veri toplama aracı olarak anket kullanılmıştır. Anket iki bölüm ve toplam 30 sorudan oluşmaktadır. Birinci bölümde katılımcıların Konya'ya yönelik bilişsel, duyuşsal ve genel imaj ile destinasyon sadakatine ilişkin algılarını belirlemek amacıyla dört adet 5'li Likert Ölçeği kullanılmıştır. Ölçekler ile ilgili bilgiler ve geliştirilirken faydalanılan literatür kaynakları Tablo 1'de gösterilmiştir.

Tablo 1. Ölçekler ve literatür kaynakları. 


\begin{tabular}{|c|c|}
\hline Ölçekler & Kaynaklar \\
\hline $\begin{array}{l}\text { Bilişsel imaj } \\
\text { (13 ifade) } \\
\text { (ölçek } 1-5) \\
\text { (1. Çok kötü, 5. Çok iyi) }\end{array}$ & (Baloğlu ve McCleary, 1999b). \\
\hline $\begin{array}{l}\text { Duyuşsal imaj } \\
\text { (4 ifade) } \\
\text { (ölçek 1-5) } \\
\text { Hiç güzel değil-Çok güzel } \\
\text { Sakin/hareketsiz - Canlı/hareketli } \\
\text { Bunaltıcı/yorucu - Rahatlatıcı/dinlendirici } \\
\text { Sıkıc1-Heyecanlı }\end{array}$ & (Baloğlu ve McCleary, 1999b). \\
\hline $\begin{array}{l}\text { Genel imaj } \\
\text { (1 ifade) } \\
\text { (ölçek } 1-5) \\
\text { (1. Çok olumlu, 5. Çok olumsuz) }\end{array}$ & (Baloğlu ve McCleary, 1999b). \\
\hline $\begin{array}{l}\text { Destinasyon sadakati } \\
\text { (2 ifade) } \\
\text { (ölçek } 1-5) \\
\text { (1.Kesinlikle katılmıyorum, 5.Kesinlikle katıllyorum) }\end{array}$ & (Chen ve Phou, 2013) \\
\hline
\end{tabular}

Ayrıca anketin birinci bölümünde Konya denildiğinde akla gelen ilk şey, Konya'yı tercih ederken yararlanılan bilgi kaynakları, sosyal medyadan yararlanılmışsa Konya ile ilgili bilgi almak için kullanılan uygulamalar ve daha önceki ziyaret miktarı sorulmuştur. Bu kapsamda dört adet Likert Ölçeğine ilave olarak birinci bölümde dört adet daha soru yer almıştır. Anketin ikinci bölümünde ise katılımcıların sosyodemografik özelliklerinin ortaya konulması amacıyla 6 adet soru yer almıştır. Bu kapsamda, yaş, cinsiyet, eğitim durumu, medeni durum, mesleki konum ve gelir düzeyine ilişkin veriler elde edilmiştir.

Anket geliştirme sürecinde oluşturulan anket öncelikle alanında uzman iki akademisyenin görüşüne sunulmuş, alınan tavsiyeler doğrultusunda ankette bazı düzeltmeler yapılmış ve anket ön deneme için hazır hale getirilmiştir. Ön deneme için hazırlanan anket araştırmanın yapılmaya başlandığı tarihten bir hafta önce hedef kitleye uygun olarak seçilen 100 kişiye uygulanmıştır. Pilot test sonucunda yapılan analizler ile ölçeklerde yer alan ifadelerin hiç birinin ölçeklerden çıkarılmasına gerek görülmemiş, ancak anket formunda yer alan bazı soruların yeterince anlaşılmadığı tespit edilmiş ve bu soruların cevaplanma oranlarını artırmak üzere gerekli düzeltmeler yapılmıştır. Ayrıca ankete ilave soru eklenmesine de gerek görülmemiştir. Bu şekilde ankete son şekli verilmiştir.

\section{3. Örneklem}

Araştırmanın evrenini Konya'ya turistik amaçlı gelen yerli turistler oluşturmaktadır. Konya kentine kendi imkânlarıyla veya günübirlik turlarla turistik amaçlı gelen yerli günübirlikçilerin sayısı kestirilememektedir. Ancak en az bir gece konaklama yapan yerli turistlerin sayısı tahmin edilebilmektedir. 2017 yılında tüm Türkiye'de turizm işletme (bakanlı) belgeli konaklama tesislerinde 24178 981, mahalli idarelerce belgelenen konaklama tesislerinde 14845256 olmak üzere toplam 39024237 yerli turist konaklama yapmıştır. Konya şehrinde ise 2017 yllında 491 367'si turizm işletme (bakanlık) belgeli konaklama tesislerinde, 417 455'i ise mahalli idarelerce belgelenen konaklama tesislerinde olmak üzere toplam 908822 yerli turist konaklama yapmıştır (Kültür ve Turizm Bakanlığı, 2018). Bir başka ifadeyle 2017 yılında konaklama yapan yerli turistlerin \% 2,3'ü Konya'da konaklama yapmıştır. Bu kapsamda evren büyüklüğü (908 822) dikkate alındığında aşağıdaki formül (Yamane, 2001) kullanılarak bu araştırmada örneklem büyüklüğü için en az 384 kişi hedeflenmiştir.

$\mathrm{n}=$

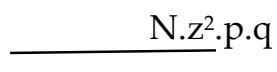


A. N. Sert - Y. Dündar 11/1 (2019) 529-544

$$
\mathrm{N} \cdot \mathrm{d}^{2}+\mathrm{z}^{2} \cdot \mathrm{p} \cdot \mathrm{q}
$$

N: yı̆̆ındaki birey sayısı

n: örneklemdeki birey sayısı

z:istenilen güvenirlik düzeyi için standart normal dağıllm tablo değeri (1.96)

d: duyarllık (araştırma için kabul edilebilir hata payı) (0.05)

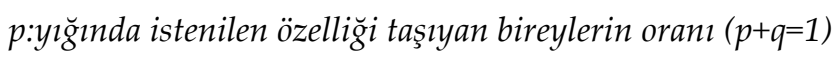

(örnek çapını maksimum yapmak için $p=q=0.50$ alınabilir)

Araştırma 22 Ekim-05 Kasım 2018 tarihleri arasında yapılmıştır. Araştırmanın başlanacağı tarihten önce Ankara' da bulunan ve öncelikle Konya şehrine tur planlaması yapan köklü bir tur operatörü yardımıyla bu tarihler arasında Konya şehrine düzenlenecek olan tur planlamaları incelenmiş, her gün düzenlenecek olan turlar arasından günübirlik turlar çıkartılarak tur programı içerisinde en az bir gece konaklamayı programına dahil eden tur organizasyonları içinden rastgele seçilen bir tur organizasyonuyla Konya'ya gelen yerli turistler hedef kitle olarak belirlenmiştir. Ayrıca her gün farklı bir tur operatörü ile gelen yerli turistler çalışma kapsamına alınmıştır. Bu doğrultuda çalışmaya Konya şehrinde daha fazla deneyim elde eden yerli turistlerin dahil edilmesi ve tur operatörünün hizmet kalitesinin şehrin imajına yönelik etkisinin asgari seviyeye indirgenmesi sağlanmıştır. Söz konusu tarihler arasında araştırmacılar tarafından anketi cevaplamayı kabul eden katılımcılarla yüz yüze görüşülerek toplam 435 anket formunun doldurulması sağlanmıştır. Uygulanan anketler sonucunda geçerli olan 405 anket değerlendirmeye tabi tutulmuştur.

\subsection{Veri Analizi}

Araştırma kapsamında ankete katılan yerli turistlerin sosyo-demografik özellikleri ile dört adet ölçek dışında yer alan sorulara verilen cevapların analizi maksadıyla sıklık ve yüzde analizlerini içeren betimleyici istatistiksel yöntemlerden yararlanılmıştır. Dört adet ölçekte yer alan ifadelere verilen cevapların analizlerinde ise aritmetik ortalama ve standart sapma analizlerini içeren betimleyici istatistiksel metotlar yanında Şekil 1'de gösterilen modelde yer alan hipotezlerin test edilmesi maksadıyla regresyon analizi kullanılmıştır. Ölçme aracından elde edilmiş ölçümlerin güvenirliği Cronbach'ın alfası ölçüm güvenirliği kestirim yöntemi ile, ölçümlerin kullanımlarının ve önerilen yorumlarının geçerliği ise faktör analizi ile belirlenmiştir. Anket verilerinin çözümlenmesinde SPSS programından yararlanılmıştır.

\section{Bulgular}

$\mathrm{Bu}$ bölümde uygulanan anket ile elde edilen verilerin analizi sonucunda ortaya çıkan bulgulara yer verilmiştir. Bu kapsamda araştırmaya dahil olan katılımcıların demografik özellikleri, Konya denildiğinde akıllarına gelen ilk şey, yararlanılan bilgi kaynakları ve sosyal medya kullanım durumu ile ziyaret sıklığına ilişkin bulguların yanında destinayon imajı ölçeğinden elde edilen ölçümlere ilişkin araştırma modeli ve hipotezleri doğrultusunda belirlenen istatistiki metotların uygulanması sonucunda ortaya çıan bulgulara yer verilmiştir.

\subsection{Demografik Bulgular}

Katılımcıların demografik özellikleri Tablo 2'de gösterilmiştir. Araştırmaya katılanların çoğunluğunu, kadın (\% 53.3), 40-49 yaş aralığında (\% 32.8), lise mezunu (\% 31.9), evli (\% 73.3), ücretli çalışan (\% 28.1) ve aylık hane halkı ortalama geliri ile ülke standartlarına göre orta gelir düzeyinde (\% 53.3) yer alan katılımcılar oluşturmaktadır. İlk önce katılımcıların gelir durumunun tespitinde aylık hane halkı ortalama gelirlerini anket üzerine yazmaları istenmiş fakat ön deneme sırasında katılımcıların çoğunluğunun gelirlerini beyan etmemek istemeleri üzerine bu soru değiştirilerek rakam belirtmemek üzere Tablo 2'de de görüldüğü gibi yeniden dizayn edilmiştir.

Tablo 2. Katılımcıların demografik özellikleri. 
A. N. Sert - Y. Dündar 11/1 (2019) 529-544

\begin{tabular}{|c|c|c|c|}
\hline Demografik özellikler & Gruplar & $f$ & $\%$ \\
\hline \multirow{2}{*}{ Cinsiyet } & Kadın & 216 & 53.3 \\
\hline & Erkek & 189 & 46.7 \\
\hline \multirow{5}{*}{ Yaş } & $18-29$ & 82 & 20.2 \\
\hline & $30-39$ & 112 & 27.7 \\
\hline & $40-49$ & 133 & 32.8 \\
\hline & $50-59$ & 68 & 16.8 \\
\hline & 60 ve daha fazla & 10 & 2.5 \\
\hline \multirow{6}{*}{ Eğitim Durumu } & Okur yazar & 9 & 2.2 \\
\hline & İlkokul mezunu & 65 & 16.1 \\
\hline & Ortaokul mezunu & 66 & 16.3 \\
\hline & Lise mezunu & 129 & 31.9 \\
\hline & Üniversite mezunu & 114 & 28.1 \\
\hline & Yüksek lisans/doktora & 22 & 5.4 \\
\hline \multirow{2}{*}{ Medeni Durum } & Evli & 297 & 73.3 \\
\hline & Bekar & 108 & 27.7 \\
\hline \multirow{7}{*}{ Meslek } & İşveren & 46 & 11.4 \\
\hline & Ǘcretli çalışan & 114 & 28.1 \\
\hline & Kendi hesabına çalışan & 80 & 19.8 \\
\hline & Öğrenci & 49 & 12.1 \\
\hline & Emekli & 21 & 5.2 \\
\hline & Ev hanımı & 83 & 20.5 \\
\hline & İşsiz & 12 & 2.9 \\
\hline \multirow{5}{*}{ Gelir Durumu } & Çok düşük & 5 & 1.2 \\
\hline & Düşük & 38 & 9.4 \\
\hline & Orta & 216 & 53.3 \\
\hline & Yüksek & 134 & 33.2 \\
\hline & Çok yüksek & 12 & 2.9 \\
\hline
\end{tabular}

\subsection{Diğer Bulgular}

Bu bölümde anketin birinci bölümünde yer alan ölçekler dışında katılımcılara yönlendirilen dört adet soruya ilişkin elde edilen verilerin analizine yer verilmiştir. Katılımcıların bu sorulara verdiği cevaplara ilişkin analizler Tablo 3'de gösterilmiştir. Katılımcıların "Bu ziyaretiniz dahil Konya'yı daha önce kaç kez ziyaret ettiniz?" sorusu dişında diğer sorulara birden fazla cevap verdikleri görülmüştür.

Katılımcılar Konya ismini duyduklarında büyük çoğunlukla (\% 51.9) öncelikle Mevlana'yı akıllarına getirmektedirler. Katılımcıların Konya'ya seyahat etmeden önce yararlandıkları bilgi kaynakları arasında aile-akraba-arkadaş-meslektaş tavsiyesi (\% 35.4) birinci sırada gelmektedir. Konya'yı tercih ederken yararlanılan bilgi kaynaklarından internet ve sosyal medya (\% 21.2) ise ikinci sırada yer almıştır. Seyahatin planlanması aşamasında internet ve sosyal medyadan yararlananların neredeyse tamamının instagram ve youtube aracılığı ile bilgi topladığı görülmüştür. Katılımcıların Konya'ya ziyaret sıklıkları incelendiğinde araştırmaya katılan yaklaşık her üç yerli turistten ikisinin araştırma sırasında yapmış olduğu ziyaretinin ilk ziyareti olmadığ̣ görülmüştür.

Tablo 3. Turistik bir destinasyon olarak Konya'ya ilişkin bulgular. 
A. N. Sert - Y. Dündar 11/1 (2019) 529-544

\begin{tabular}{|c|c|c|c|}
\hline Sorular & Gruplar & $f$ & $\%$ \\
\hline \multirow{8}{*}{$\begin{array}{l}\text { Konya denildiğinde aklınıza ilk gelen } \\
\text { şey nedir? } \\
(n=455)\end{array}$} & Mevlana & 236 & 51.9 \\
\hline & $\begin{array}{l}\text { Etliekmek (Konya'ya özgü uzun ve ince etli } \\
\text { pide) }\end{array}$ & 48 & 10.5 \\
\hline & Sille (tarihi bir yerleşim yeri) & 46 & 10.1 \\
\hline & $\begin{array}{l}\text { Meram (Konya'nın yeşil alanları ile ünlü } \\
\text { merkez ilçesi) }\end{array}$ & 32 & 7 \\
\hline & Yemekler (pilav, çorba, kebap, şeker) & 30 & 6.6 \\
\hline & $\begin{array}{l}\text { Şems-i Tebrizi (türbesi Konya'da yer alan } \\
\text { büyük din alimi) }\end{array}$ & 19 & 4.2 \\
\hline & $\begin{array}{l}\text { Alâeddin Tepesi (Konya merkezinde bulanan } \\
\text { bir höyük) }\end{array}$ & 16 & 3.5 \\
\hline & Diğer (cevaplarda 18 ayrı ifade bulunmaktadır) & 28 & 6.2 \\
\hline \multirow{10}{*}{$\begin{array}{l}\text { Konya'yı tercih ederken hangi bilgi } \\
\text { kaynağından/kaynaklarından } \\
\text { yararlandınız? } \\
(n=622)\end{array}$} & Aile-akraba-arkadaş-meslektaş tavsiyesi & 220 & 35.4 \\
\hline & TV-radyo & 36 & 5.8 \\
\hline & Rehber kitaplar & 19 & 3.1 \\
\hline & Önceki ziyaretler & 96 & 15.4 \\
\hline & İnternet-sosyal medya & 132 & 21.2 \\
\hline & Gazete-dergi & 13 & 2.1 \\
\hline & Seyahat acentesi/tur operatörü & 18 & 2.9 \\
\hline & Seyahat ve turizm fuarları & 43 & 6.9 \\
\hline & Okuldan öğrenilen genel bilgiler & 18 & 2.9 \\
\hline & Diğer & 27 & 4.3 \\
\hline \multirow{8}{*}{$\begin{array}{l}\text { Sosyal medyadan yararlandıysanız } \\
\text { Konya ile ilgili bilgi almak için hangi } \\
\text { uygulamayı kullandınız? } \\
(n=456)\end{array}$} & Facebook & 64 & 14.1 \\
\hline & Twitter & 43 & 9.4 \\
\hline & Instagram & 132 & 28.9 \\
\hline & Youtube & 131 & 28.7 \\
\hline & Bloglar & 6 & 1.3 \\
\hline & Pinterest & 3 & 0.7 \\
\hline & Wikipedia & 9 & 2 \\
\hline & Diğer & 68 & 14.9 \\
\hline \multirow{4}{*}{$\begin{array}{l}\text { Bu ziyaretiniz dahil Konya'yı daha önce } \\
\text { kaç kez ziyaret ettiniz? } \\
(n=405)\end{array}$} & Bu ilk ziyaretim & 148 & 36.5 \\
\hline & İki defa & 96 & 23.7 \\
\hline & Üç defa & 78 & 19.3 \\
\hline & Dört veya daha fazla & 83 & 20.5 \\
\hline
\end{tabular}

\section{3. Ölçeklerden Elde Edilmiş Ölçümler}

Ölçeklerden elde edilmiş ölçümler Tablo 4'de gösterilmiştir. Yapılan güvenirlik ve geçerlik analizleri sonucunda bilişsel imaj ölçeğinden bir madde (güvenlik ve kişisel emniyeti) ölçekten çıkartılmıştır. Bilişsel imaj ölçeği için Cronbach'ın alfası ile hesaplanan ölçüm güvenirliği katsayısı 0.793, duyuşsal imaj ölçeği için 0.722 , destinasyon sadakati ölçeği için 0.799 'dur.

Bilişsel, duyuşsal ve destinasyon sadakati ölçekleri KMO ve Bartlett Test sonuçlarına göre (KMO $\geq 0.50$, $p$ $<0.01$ ) veri seti faktör analizi için uygundur. Faktör analizinde özdeğer istatistiği (eigenvalue) 1'den büyük olan faktörler anlamlı olarak belirlenmiştir. Bilişsel imaj ölçeğinde özdeğeri 1'den büyük olan 4 faktör söz konusudur. Duyuşsal imaj ölçeğinde ise özdeğeri 1'den büyük olan 2 faktör, destinasyon sadakati ölçeğinde de 1 faktör söz konusudur. Bilişsel imaj ölçeğinde faktörlerin toplam açıklanan varyansı \% 58.866, duyuşsal imaj ölçeğinde \%78.803, destinasyon sadakati ölçeğinde ise \% 83.591 olarak belirlenmiştir.

Tablo 4. Ölçümler. 
A. N. Sert - Y. Dündar 11/1 (2019) 529-544

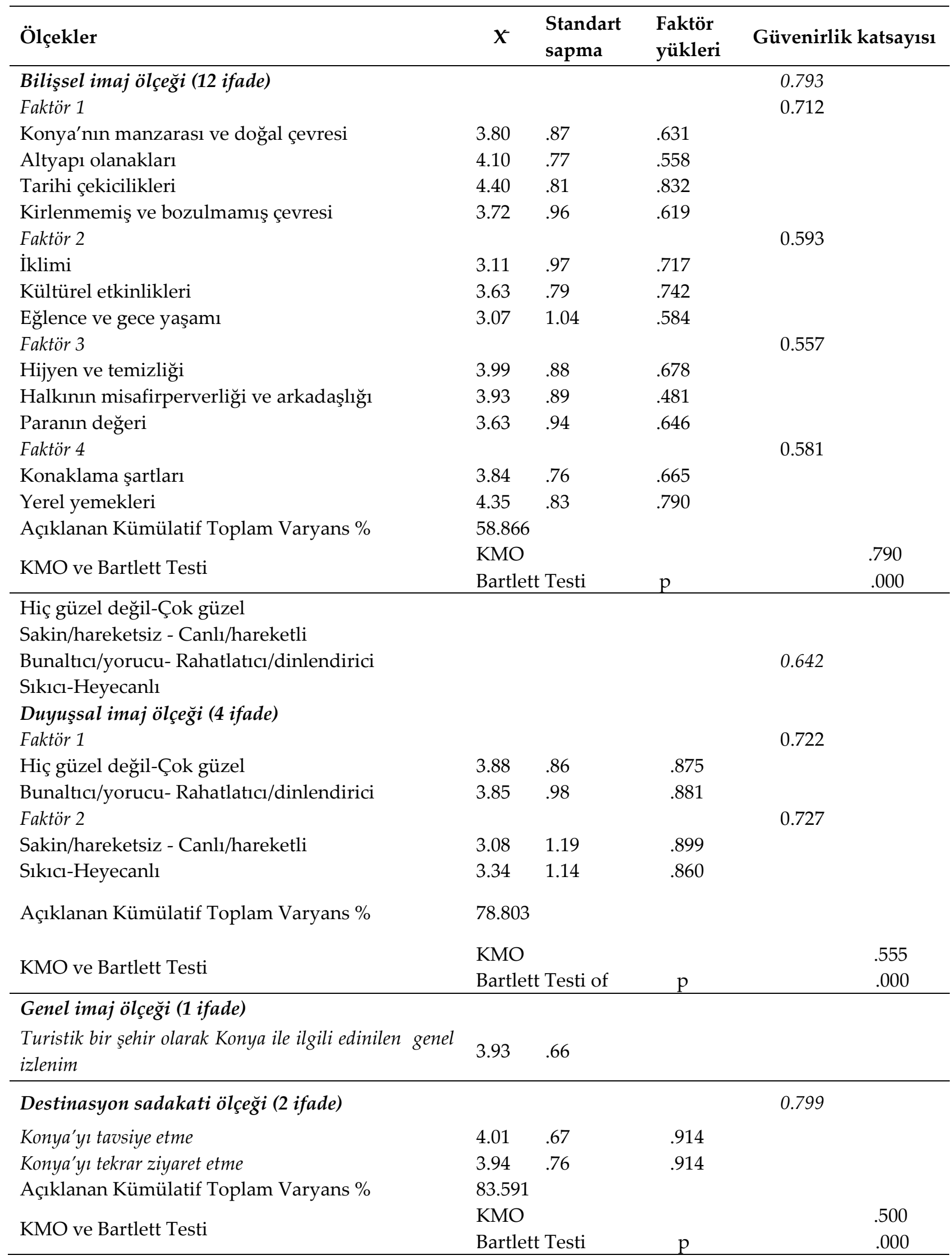

\subsection{Hipotezlerin Testi}

Hipotezler regresyon analizi ile test edilmiştir. Regresyon analizi ayrıntılı sonuçları Tablo 5'de gösterilmiştir. Öncelikle bilişsel ve duyuşsal imaj (bağımsız değişkenler) ile genel imaj (bağımlı değişken) değişkenlerinin birlikte aynı anda regresyon analizine dahil edilip edilemeyeceği, bir başka ifadeyle aralarındaki ilişkinin çoklu doğrusal regresyon analizi ile test edilip edilemeyeceği analiz edilmiştir. Çoklu doğrusal regresyon 
analizinin kullanımında karşılanması gereken en önemli ön koşullar bağımlı değişkenin normal bir dağılıma sahip olması ve bağımsız değişkenler arasında çoklu bağıntı (multicollinearity) probleminin olmamasıdır.

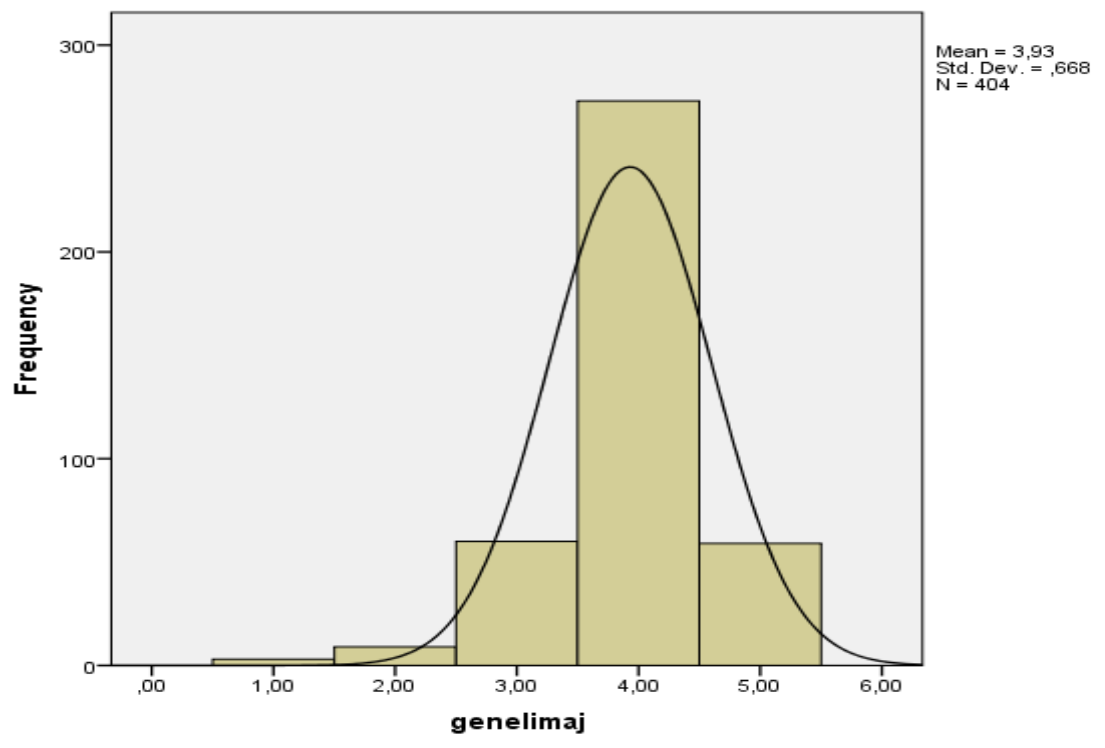

Şekil 2. Bağımlı değişkene ait dağılım.

Şekil 2'deki histogramda görüleceği üzere bağımlı değişken (genel imaj) yaklaşık olarak normal bir dağılıma sahiptir.

Tablo 5. Regresyon analizinin sonuçları.

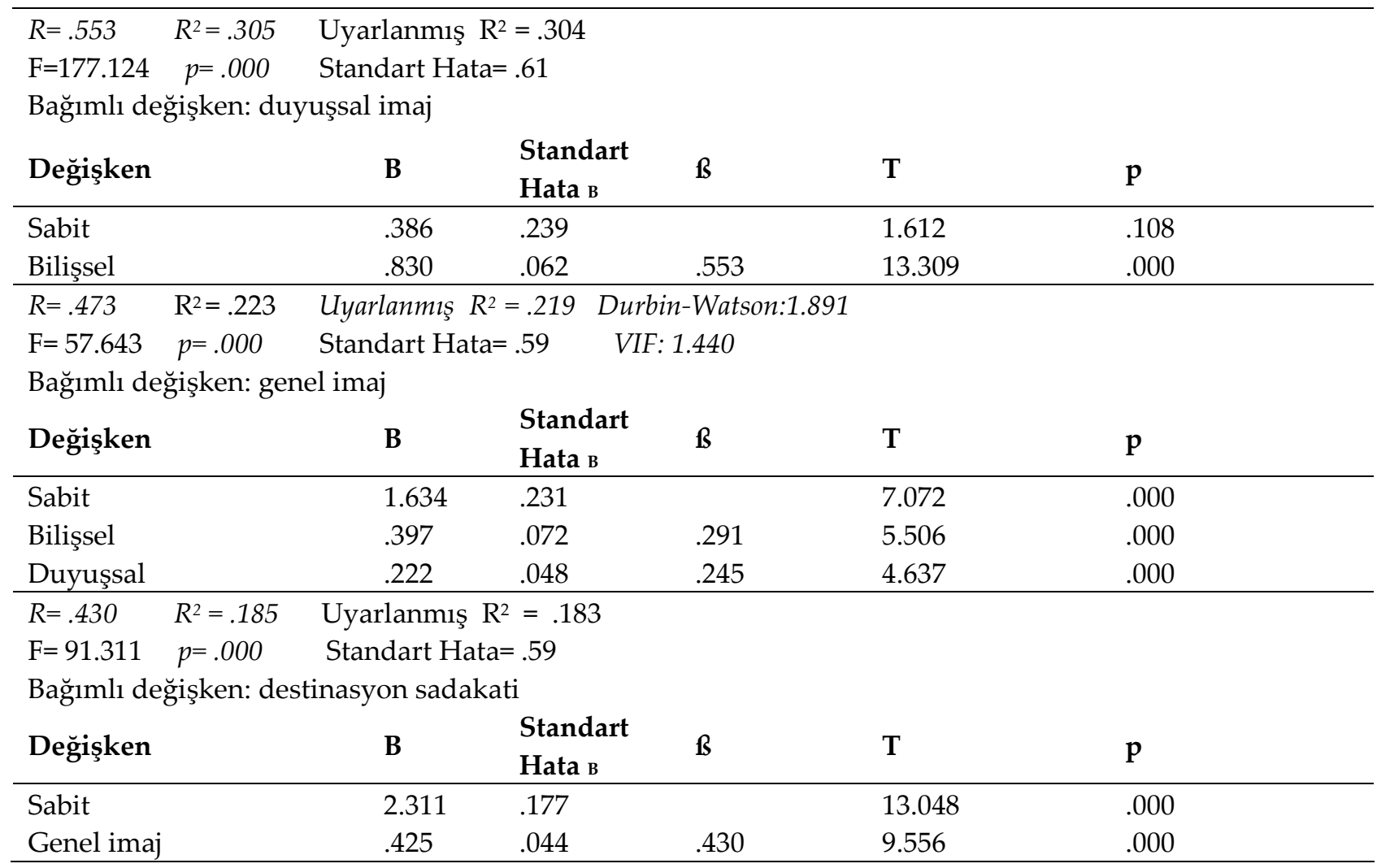

Tablo 5'de görüldüğü gibi bilişsel imaj ve duyuşsal imaj değişkenleri arasındaki pearson korelasyon katsayısı çok yüksek değildir, bir başka ifadeyle aralarında çok yüksek bir korelasyon bulunmamaktadır $(\mathrm{r}=.553<.70) . \mathrm{Bu}$ bağımsız değişkenler arasında çoklu bağıntı bir diğer ifadeyle benzeşiklik şüphesinin oluşmadığı şeklinde yorumlanabilmektedir. Çoklu bağıntı şüphesi regresyon analizi çıktılarından VIF (varyans genişlik fakötürü) değeri aracılığı ile de tespit edilmektedir. Tablo 5'de sunulduğu üzere VIF değeri $(1.440<5)$ bağımsız değişkenler arasında çoklu bağıntı şüphesinin olmadığını göstermektedir. Ayrıca çoklu 
regresyon analizi için oto-korelasyon (auto-correlation) yani bağımsız değişkenlerin hata terimleri arası korelasyon olmaması koşulu da sağlanmalıdır. Regresyon modelinde oto-korelasyon şüphesinin olup olmadığı Durbin-Watson analizi ile sinanmaktadır. Tablo 5'de görülebileceği üzere 0 ile 4 arasında değer almakta olan ve 2 değeri aldığında bağımsız değişkenlerin hata terimleri arası korelasyon olmadığını gösteren Durbin-Watson değerinin (1.891) yaklaşık 2'ye yakın değer alması nedeniyle bağımsız değişkenlerin hata terimleri arası korelasyon olmadığı bir başka ifadeyle çoklu doğrusal regresyon analizi için sağlanması gereken oto korelasyon sorununun olmadığı söylenebilmektedir.

Sonuç olarak genel imaj değişkenini etkileyen bilişsel ve duyuşsal imaj değişkenlerinin aynı anda regresyon analizinde kullanılabileceği ve analiz esnasında iki değişken birbirini kontrol edemeyeceğinden her iki değişkenin de regresyon modelinde kalmasının uygun olduğu belirlenmiştir. Bu kapsamda bilişsel ve duyuşsal imajın genel imaja etkisi çoklu doğrusal regresyon analizi ile bilişsel imajın duyuşsal imaja etkisi ve genel imajın destinasyon sadakatine etkisi basit doğrusal regresyon analizi ile test edilmiştir.

Regresyon modeli Şekil 3'de sunulmuş olup, Tablo 5'deki analiz sonuçlarına göre model bir bütün halinde istatistiksel olarak anlamlıdır ( $\mathrm{p}=.000<.01)$. Analiz sonuçları model üzerinde yorumlandığında bilişsel imaj ile duyuşsal imaj arasındaki ilişki istatistiksel olarak anlamlı bulunmuştur ( $\mathrm{p}<.01$ ). Bilişsel imaj duyuşsal imajı pozitif yönde ve anlamlı bir şekilde etkilemektedir $(\mathrm{r}=.553)$. Ayrıca determinasyon katsayısı $\left(r^{2}\right) .305$ olarak hesaplanmış olup, duyuşsal imajdaki değişimlerin \% 30.5'inin bilişsel imaja bağlı olduğu söylenebilir. Bu kapsamda H1 hipotezi desteklenmiş olup regresyon modeli aşağıda gösterilmiştir.

$Y($ duyuşsal imaj $)=0.386+0.830 X$ (bilişsel imaj)

Bununla birlikte bilişsel imaj ve duyuşsal imaj ile genel imaj arasındaki ilişki istatistiksel olarak anlamlı bulunmuştur $(\mathrm{p}<.01)$. Bilişsel imaj ve duyuşsal imaj genel imajı pozitif yönde ve anlamlı bir şekilde etkilemektedir $(\mathrm{r}=.473)$. Ayrıca uyarlanmış determinasyon katsayısına bakıldığında (uyarlanmış $\mathrm{r}^{2}$ ) genel imajdaki değişimlerin \% 21.9'unun bilişsel ve duyuşsal imaja bağlı olduğu söylenebilir. Ayrıca (ß) değerleri incelendiğinde bilişsel imajin ( $(=.291)$ duyuşsal imaja $(\Omega=.245)$ oranla genel imajı kısmen daha fazla etkilediği görülmektedir. Bu kapsamda $\mathrm{H} 2$ ve $\mathrm{H3}$ hipotezleri desteklenmiş olup regresyon modeli aşağıda sunulmuştur.

$Y($ genel imaj $)=1.634+0.397 X_{1}($ bilişsel imaj $)+0.222 X_{2}($ duyuşsal imaj $)$

Son olarak yapılan analizle genel imaj ile destinasyon sadakati arasındaki ilişki istatistiksel olarak anlamlı bulunmuştur $(\mathrm{p}<.01)$. Genel imaj destinasyon sadakatini pozitif yönde ve anlamlı bir şekilde etkilemektedir $(\mathrm{r}=.430)$. Ayrıca determinasyon katsayısına $\left(\mathrm{r}^{2}\right)$ bakıldığında; destinasyon sadakatindeki değişimlerin \% 18.5'inin genel imaja bağlı olduğu söylenebilir. Bu kapsamda H4 hipotezi desteklenmiş olup regresyon modeli aşağıda sunulmuştur.

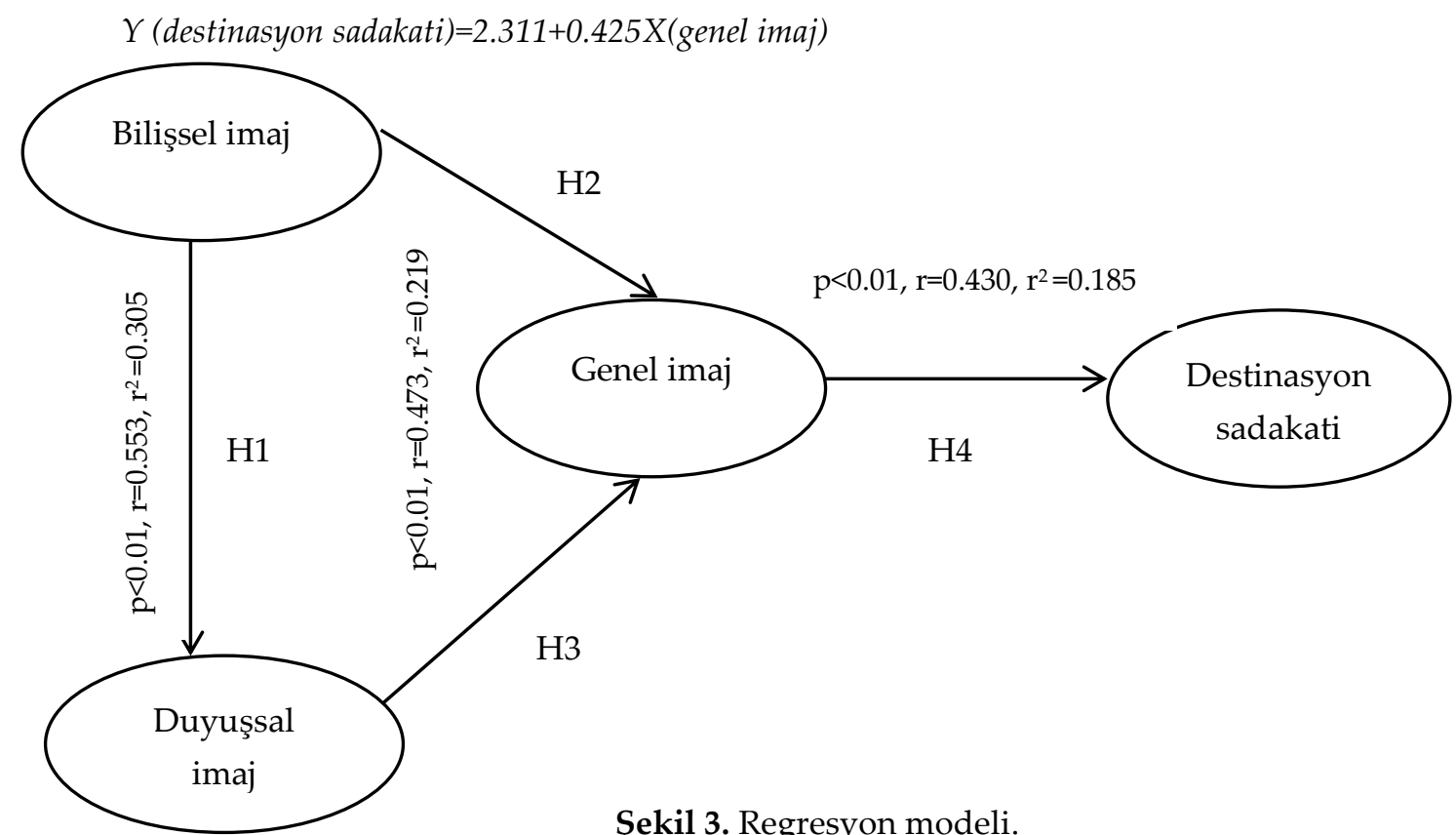

Şekil 3. Regresyon modeli.

\section{Sonuç ve Tartışma}


Destinasyon imajı, destinasyonun seçilmesi aşamasıyla sınırlı değildir (Chen ve Tsai, 2007). Destinasyon imajının değerlendirilmesi ve analizi, turist davranışının daha iyi anlaşılmasına önemli bir katkıda bulunmaktadır (Beerli ve Martin, 2004). Bu nedenle, destinasyon imajını oluşturmaya veya geliştirmeye yönelik çabalar, sadık ziyaretçilerin tekrar ziyaret veya tavsiye etme davranışlarını kolaylaştırır ki söz konusu durum destinasyonun turizm gelişimi konusundaki başarısı için kritik öneme sahiptir. Turistlerin destinasyonla ilgili edindikleri imajı belirlemek, destinasyonunun güçlü ve zayıf yanlarını ortaya koymak, pazarlama çalışmalarını etkin bir şekilde yerine getirmek, destinasyon imajını yönetmek ve dolayısıyla rekabet başarısını garanti altına almak için gereklidir (San Martin ve del Bosque, 2008). Buna bağlı olarak destinasyon pazarlamacılarının temel amacı, destinasyonla ilgili olumlu bir imaj oluşturmak ve kendilerini rakiplerinden ayırmaktır (Baloğlu ve McCleary, 1999a).

Çalışmadan elde edilen bulgulara göre bilişsel imaj duyuşsal imajı pozitif yönde ve anlamlı olarak etkilemektedir. Bilişsel imajın ölçümü genellikle destinasyonun fiziksel özellikleri ve nitelikleri üzerinden yapılmaktadır. Bu çalışmada da yerli turistlerin Konya'ya ilişkin algıladıkları bilişsel imajın ölçümü Konya'nın doğal çevresi, altyapı olanakları, tarihi ve kültürel çekicilikleri, iklimi, eğlence olanakları, hijyen ve temizliği, konaklama imkanları, gastronomi, misafirperverlik ve paranın değeri gibi özellikler dikkate alınarak ölçülmüştür. Elde edilen bulgulara göre yerli turistlerin Konya'yı genel olarak olumlu değerlendirdiği, özellikle tarihi çekicilikleri, yerel yemekleri ve altyapı olanaklarının diğer ifadelere oranla daha yüksek aritmetik ortalamaya sahip oldukları görülmektedir. En düşük ortalamaya sahip olan ise eğlence ve gece yaşamı olmuştur.

Bilişsel imajın ölçümü destinasyonun niteliklerine yönelik düşüncelerden oluşurken duyuşsal imaj ölçümü destinasyon ile ilgili hislerden oluşmaktadır. Yapılan çalışmada kullanılan ölçekte duygu durumu ile ilgili bir uçta en olumlu ifadeler yar alırken diğer uçta en olumsuz duyguyu belirten ifadeler bulunmaktadır (hiç güzel değil-çok güzel, sakin/hareketsiz-canl1/hareketli, bunaltıc1/yorucu-rahatlatıc1/dinlendirici, sıkıc1heyecanlı). Elde edile bulgulara göre araştırmaya katılan yerli turistlerin genel olarak Konya'da kendilerini iyi hissettikleri özellikle Konya'yı güzel ve rahatlatıcı buldukları gözlemlenmiştir. Ancak kısmen Konya'yı hareketsiz ve sıkıcı olarak değerlendirmektedirler.

Doğal, tarihi ve kültürel çekicilikleriyle zengin turistik destinasyonların imajlarını öncelikle somut objeler üzerine kurgulaması son derece doğaldır. Bu tür destinasyonlarda da ziyaretçiler gözle gördükleri fiziksel özellikler ile destinasyon hakkında duygu durumunu belirlerler. Ancak bu somut objelere de bir anlam yüklenmesi gerekmektedir. Çalışma alanı olarak Konya şehrinin tarihi çekicilikleri Mevlana'nın maneviyatı ile bütünleşmektedir. Bilişsel imajın duyuşsal imajı etkilediği göz önünde bulundurulduğunda Konya'nın fiziksel çekiciliklerini ön plana çıkararak ziyaretçilerin duygularına yön vermesi gerekmektedir. Çalışmada bilişsel imajın duyuşsal imaja etkisi kısmen olumsuz olarak değerlendirilen eğlence ve gece yaşamı olanaklarının turistlerin Konya'yı kısmen hareketsiz ve sıkıcı olarak değerlendirmelerine neden olmasında görülebilmektedir. Konya'nın eğlence ve gece yaşamı olanaklarını biraz geliştirmesi gerekmektedir.

Çalışmanın ortaya çıkan bulgularından diğeri bilişsel ve duyuşsal imajın genel imajı pozitif yönde ve anlamlı olarak etkilediğidir. Destinasyon imajı bilişsel, duyuşsal ve genel imaj olmak üzere üç önemli boyuttan oluşmaktadır. Bilişsel ve duyuşsal imaj genel imaj oluşumunda en önemli iki bileşendir. Çalışmada yerli turistlerin turistik bir şehir olarak Konya ile ilgili edindikleri genel izlenim genel olarak olumludur. Bu kapsamda elde edilen en önemli bulgu bilişsel imajın kısmen duyuşsal imaja oranla genel imajı daha fazla etkilediğidir. Zengin doğal, tarihi ve kültürel zenginlikleri olan destinasyonların olumlu bir imaj yaratmada fiziksel özelliklerini geliştirmeye daha çok önem vermeleri gerekmektedir. Fakat turistik çekicilik olarak zayıf destinasyonların duyuşsal imaj boyutuna daha fazla önem vererek olumlu imaj yaratmada başarılı oldukları da görülmektedir. Örneğin ortaya atılan ve kulaktan kulağa yayılan bir efsane hiçbir doğal çekiciliği olmayan destinasyonları dünyanın en popüler destinasyonları arasına sokabilmektedir. Çalışma alanı olan Konya özellikle tarihi çekicilikleri başta olmak üzere gastronomisini ön plana çıkartarak olumlu bir genel imaj yaratmada firsat yakalayabilir.

Çalışmanın ortaya çıkan bulgularından bir diğeri ise genel imajın destinasyon sadakatini pozitif yönde ve anlamlı olarak etkilediğidir. Çalışma sonuçlarına göre yerli turistlerin büyük çoğunlukla Konya'yı yakın çevresine tavsiye edeceği ve Konya' yı tekrar ziyaret edeceği tespit edilmiştir. Katılımcıların Konya'ya ziyaret sıklıkları incelendiğinde araştırmaya katılan yaklaşık her üç yerli turistten ikisinin araştırma sırasında 
A. N. Sert - Y. Dündar 11/1 (2019) 529-544

yapmış olduğu ziyaretinin ilk ziyareti olmadığı sonucu da elde edilen sonucu desteklemektedir. Çalışmada elde edilen bulgulardan yerel turistlerin Konya'dan memnun olduklarına yönelik bir çıkarımda bulunabilmek mümkündür. Konya'nın olumlu imajını korumasında ve destinasyon sadakatini geliştirmesinde tarihi çekicilikleri ön plana çıkmaktadır. Konya'nın en büyük değeri olan Mevlana'nın Konya'nın tanıtımında ön plana çıkartılması gerekmektedir. Mevlana sadece yerel turist hareketliliğinin geliştirilmesinde dikkate alınacak bir değer olmamalıdır. Mevlana'nın Konya'ya yabancı turist akışının sağlanmasında da uluslararası alanda etkin bir şekilde tanıtılmasına ihtiyaç bulunmaktadır.

$\mathrm{Bu}$ çalışma ile, müşterilerin satın aldıkları mal/hizmet ya da işletme hakkındaki görüşlerini çevreleri ile paylaşmaları olarak tanımlanan (Eru ve Köroğlu, 2015) kulaktan kulağa pazarlamanın destinasyon pazarlamasındaki önemi bir kez daha vurgulanmıştır. Bununla birlikte diğer pazarlama araçlarının etkin kullanılamadığı sonucuna ulaşılabilir. Günden güne internet ve sosyal medya kullanıcılarının sayılarında artış yaşandığı da bilinen bir gerçektir. Mevlana ile bütünleşen Konya'nın mutlaka sosyal medya platformlarında etkili bir şekilde yer alması gerekmektedir. Turistik bir destinasyon olarak Konya'nın pazarlama ve tanıtım sorumlularının özellikle görsel içeriğe önem veren sosyal medya platformlarını titizlikle takip etmesi ve etkin bir şekilde kullanması gerekmektedir. Ayrıca Konya'da gelen turistlerin kolaylıkla bulabileceği ve bilgi alabileceği turizm danışma merkezleri de olmalıdır. Bu merkezlerde turistler Konya'nın tarihi zenginlikleri yanında yöresel yemeklerinin neler olduğu ve nerelerde yenebileceği konusunda bilgilere de ulaşabilmelidirler. Söz konusu çalışma çoğunlukla inanç ve kültür turizmi kapsamında Konya'ya seyahat eden yerli turistler ile sınırlıdır. Alternatif turizm türleri bakımından gelişmiş diğer destinasyonlarda yerli ve yabancı turistler üzerine yapılacak çalışmalar ile elde edilecek bulgularla genel bir yargıya ulaşılması mümkündür.

\section{Kaynakça}

Baloğlu, S., \& McCleary, K. W. (1999a). A model of destination image formation. Annals of Tourism Research, $26(4), 868-897$.

Baloğlu, S., \& McCleary, K. W. (1999b). US international pleasure travelers' images of four Mediterranean destinations: A comparison of visitors and nonvisitors. Journal of Travel Research, 38(2), 144-152.

Baloğlu, S., \& Mangaloglu, M. (2001). Tourism destination images of Turkey, Egypt, Greece, and Italy as perceived by US-based tour operators and travel agents. Tourism Management, 22(1), 1-9.

Baloğlu, S., Henthorne, T. L., \& Sahin, S. (2014). Destination image and brand personality of Jamaica: A model of tourist behavior. Journal of Travel \& Tourism Marketing, 31(8), 1057-1070.

Beerli, A., \& Martin, J. D. (2004). Factors influencing destination image. Annals of Tourism Research, 31(3), 657681.

Chen, C. F., \& Phou, S. (2013). A closer look at destination: image, personality, relationship and loyalty. Tourism Management, 36, 269-278.

Chen, C. F., \& Tsai, D. (2007). How destination image and evaluative factors affect behavioral intentions? Tourism Management, 28(4), 1115-1122.

Chew, E. Y. T., \& Jahari, S. A. (2014). Destination image as a mediator between perceived risks and revisit intention: A case of post-disaster Japan. Tourism Management, 40(1), 382-393.

Crompton, J. L. (1979). An assessment of the image of Mexico as a vacation destination and the influence of geographical location upon the image. Journal of Travel Research, 18(4), 18-23.

del Bosque, I. R., \& San Martín, H. (2008). Tourist satisfaction a cognitive-affective model. Annals of Tourism Research, 35(2), 551-573.

Eru, O., \& Köroğlu, Ç. (2015). Kulaktan Kulağa Pazarlamanın Mali Müşavir-Muhasebeci Seçimine Etkisi. International Journal of Social Sciences and Education Research, 1(4), 1041-1052.

Echtner, C. M., \& Ritchie, J. B. (1991). The meaning and measurement of destination image. Journal of Tourism Studies, 2(2), 2-12. 
A. N. Sert - Y. Dündar 11/1 (2019) 529-544

Echtner, C. M., \& Ritchie, J. R. B. (1993). The measurement of destination image: An empirical assessment. Journal of Travel Research, 31(4), 3-13.

Fakeye, P. C., \& Crompton, J. L. (1991). Image differences between prospective, first time, and repeat visitors to the Lower Rio Grande Valley. Journal of Travel Research, 30(2), 10-16.

Gartner, W. C., \& Shen, J. (1992). The impact of Tiananmen Square on China's tourism image. Journal of Travel Research, 30(4), 47-52.

Hosany, S., \& Prayag, G. (2013). Patterns of tourists' emotional responses, satisfaction, and intention to recommend. Journal of Business Research, 66(6), 730-737.

Hosany, S., Ekinci, Y., \& Uysal, M. (2007). Destination image and destination personality. International Journal of Culture, Tourism and Hospitality Research, 1(1), 62-81.

Hunt, J.D. (1975). Image as a factor in tourism development. Journal of Travel Research, 13(3), 1-7.

Jacoby, J., \& Chesnut, R. W. (1978). Brand loyalty measurement and management. New York: Wiley \& Sons.

Kock, F., Josiassen, A., \& Assaf, A. G. (2016). Advancing destination image: the destination content model. Annals of Tourism Research, 61(1), 28-44.

Kültür ve Turizm Bakanlığ1 (2018). Turizmde ürün çeşitliliği. http://yigm.kulturturizm.gov.tr/TR9980/konya.html (Erişim Tarihi: 15.08.2018).

Lin, C. H., Morais, D. B., Kerstetter, D. L., \& Hou, J. S. (2007). Examining the role of cognitive and affective image in predicting choice across natural, developed, and theme-park destinations. Journal of Travel Research, 46(2), 183-194.

Milman, A., \& Pizam, A. (1995). The role of awareness and familiarity with a destination: The Central Florida case. Journal of Travel Research, 33(3), 21-27.

Oliver, R. L. (1999). “Whence Consumer Loyalty?” Journal of Marketing, 6(1), 33-44.

Oppermann, M. (2000). Predicting destination choice-a discussion of destination loyalty. Journal of Vacation Marketing, 5(1), 51-65.

Pike, S. (2002). Destination image analysis: a review of 142 papers from 1973-2000. Tourism Management, 23(5), 541-549.

Pike, S. (2016). Destination image: identifying baseline perceptions of Brazil, Argentina and Chile in the nascent Australian long haul travel market. Journal of Destination Marketing \& Management, 5(2), 164170.

Prayag, G., \& Ryan, C. (2012). Antecedents of tourists' loyalty to Mauritius: the role and influence of destination image, place attachment, personal involvement, and satisfaction. Journal of Travel Research, 51(3), 342-356.

Ross, G. F. (1993). Ideal and actual images of backpacker visitors to Northern Australia. Journal of Travel Research, 32(2), 54-57.

San Martín, H., \& del Bosque, I. A. R. (2008). Exploring the cognitive-affective nature of destination image and the role of psychological factors in its formation. Tourism Management, 29(2), 263-277.

Souiden, N., Ladhari, R., \& Chiadmi, N. E. (2017). Destination personality and destination image. Journal of Hospitality and Tourism Management, 32(1), 54-70.

Smith, W. W., Li, X. R., Pan, B., Witte, M., \& Doherty, S. T. (2015). Tracking destination image across the trip experience with smartphone technology. Tourism Management, 48(1), 113-122.

Stylidis, D., Shani, A., \& Belhassen, Y. (2017). Testing an integrated destination image model across residents and tourists. Tourism Management, 58(1), 184-195.

Sun, X., Chi, C. G. Q., \& Xu, H. (2013). Developing destination loyalty: the case of Hainan Island. Annals of Tourism Research, 43(1), 547-577. 
A. N. Sert - Y. Dündar 11/1 (2019) 529-544

Tan, W. K., \& Wu, C. E. (2016). An investigation of the relationships among destination familiarity, destination image and future visit intention. Journal of Destination Marketing \& Management, 5(3), 214226.

Taşc1, A. D., \& Gartner, W. C. (2007). Destination image and its functional relationships. Journal of Ttravel Research, 45(4), 413-425.

Taşc1, A. D., Gartner, W. C., \& Çavuşgil, S. (2007). Conceptualization and operationalization of destination image. Journal of Hospitality \& Tourism Research, 31(2), 194-223.

$\mathrm{Wu}, \mathrm{C}$. (2016). Destination loyalty modeling of the global tourism. Journal of Business Research, 69(6), 22132219.

Xu, H., \& Ye, T. (2018). Dynamic destination image formation and change under the effect of various agents: The case of Lijiang,'The Capital of Yanyu'. Journal of Destination Marketing \& Management, 7, 131-139.

Yamane, T. (2001). Temel örnekleme yöntemleri. (Çev. A. Esin, M. A. Bakır, C. Aydın, E.Gürbüzsel). İstanbul: Literatür Yayınları.

Yoon, Y., \& Uysal, M. S. (2005). An examination of the effects of motivation and satisfaction on destination loyalty: a structural model. Tourism Management, 26(1), 45-56.

Zhang, H., Fu, X., Cai, L. A., \& Lu, L. (2014). Destination image and tourist loyalty: a meta-analysis. Tourism Management, 40(1), 213-223.

Zhang, H., Wu, Y., \& Buhalis, D. (2018). A model of perceived image, memorable tourism experiences and revisit intention. Journal of Destination Marketing EManagement, 8(1), 326-336. 